Brit. J. vener. Dis. (1964), 40, 228.

\title{
OBITUARY
}

\section{COLONEL LAWRENCE WHITAKER HARRISON, C.B, D.S.O, F.R.C.P.Ed. 1876-1964}

The death of Colonel Harrison is a matter of deep regret to all concerned with the subject of venereology, at home and abroad. He was born in 1876 and received his medical education at Glasgow, where he qualified in 1897. He became F.R.C.P. Ed. in 1925. His military career began in 1899 and during the South African war he was mentioned in dispatches. During the war of 1914 to 1918 he was again mentioned in dispatches, twice, and received the D.S.O. He was, originally, a pathologist in a Service which has always been noted for its high standards in this particular discipline. In Medicine Illustrated of July and August, 1949, he gave a fascinating account of his first contact with the subject of venereology and described how, unwilling though he was at first, the subject claimed him for its own. In his subsequent career in the Army, at St. Thomas's Hospital, and as Adviser to the Ministry of Health, he brought all his qualities of devotion, of fearlessness, of meticulous accuracy and unswerving honesty to this despised and neglected subject. In Great Britain he was the father of the Venereal Diseases Service and during a long life fought unremittingly to raise its standing and improve its standards. He was the author of three text-books on the venereal diseases and made many contributions to the literature of the subject. He was a founder member and chief support of the Medical Society for the Study of Venereal Diseases and, with E. R. T. Clarkson, was joint editor of the British Journal of Venereal Diseases from its inauguration in 1925 to 1939 , becoming sole editor from 1939 to 1942. For many years he supported both organizations with devotion and complete selflessness and in 1961 contributed to the latter a detailed and precise history of the Society's inception and of the first $\mathbf{3 0}$ years of its work.

He was a truly remarkable man and will be greatly missed. We have taken the opportunity of asking some of those who were associated with him over the years to pay a tribute to his memory:

BRIGADIER T. E. Osmond writes: "I think I can say without fear of contradiction that I knew Colonel Harrison longer and more intimately than any of his medical colleagues. I first served under him at Rochester Row in 1912-13 and later from the end of

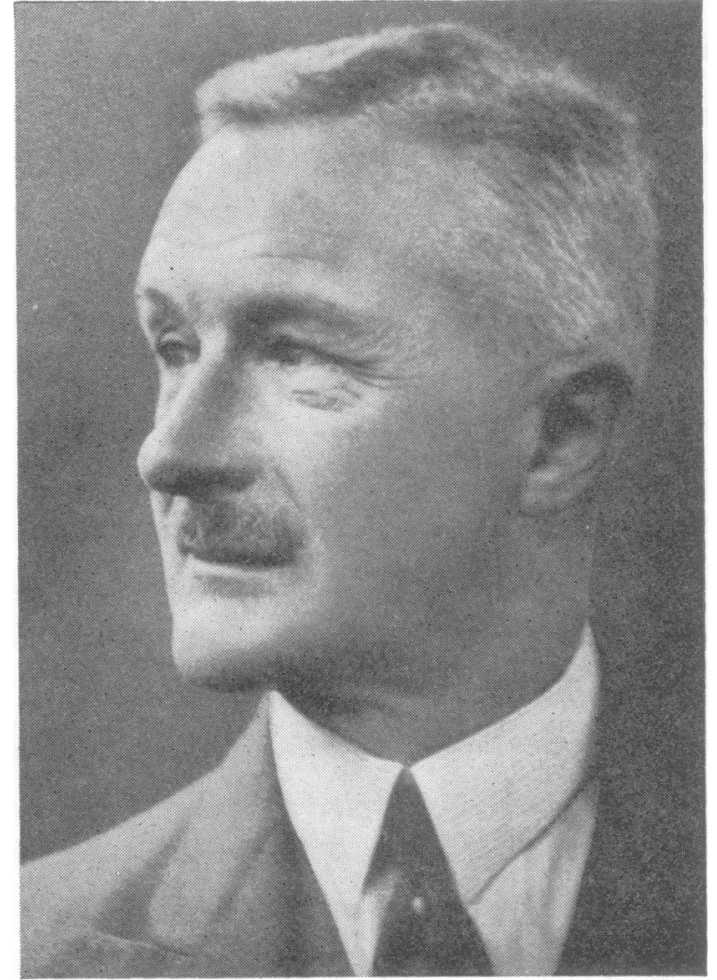

World War I till his retirement at St. Thomas's Hospital: any small success I may have gained has been entirely due to him. He had a great brain and was, perhaps, the outstanding venereologist of the century. It is not for me to recount his attainments but I cannot too strongly stress what a charming character he was; what a loyal frierd, what an understanding friend, and what a wise counsellor. The Profession, indeed the world, is all the worse for his death and there will be many, in high places and low, who will miss him and deeply regret his passing. Our sympathy goes out to his widow and family."

Dr G. L. M. McElligotr has added the following: "I am glad, grateful, and not a little proud to have been trained in Harrison's clinic at St. 
Thomas's nearly 40 years ago. Though a good doctor, the Colonel was essentially a soldier. This was just as well, as, in founding a new specialty, a fighter was needed. That he was not particularly popular with the honorary staff is perhaps understandable, for his department quickly acquired a national, and indeed an international, reputation and this they found difficult to understand. It was, though, to their shame that they never elected him member of their medical committee. Though located in most unpromising premises-a big army hut with a tree growing through its floor and roof-his clinic was not only a prototype but a model. It was designed, not only to ensure a rapid and efficient diagnosis and treatment, but also the maximum of privacy for the patient. With Harrison the patient always came first. An experienced bacteriologist and serologist, he attached great importance to his laboratory, which for many years was in the capable hands of a retired brother officer, Captain (later Brigadier) Osmond. It is significant that, even back in the 1920s he insisted on his clinical assistants spending at least a month with Osmond, who taught them not how to become serologists, but rather to understand the principles, difficulties, and limitations of laboratory work - invaluable experience for a budding clinician. Finally, the man; a handsome, honourable, hard-working, shrewd north-countryman, full of dry humour and a kindliness which he did his best, quite unsuccessfully, to conceal. Though he despised and was quick to recognize frauds, he had only one hatred, injustice, and he instinctively fought hard for anyone he thought was getting a rough deal. When he detected unfairness in any guise, he was liable to see red and was not particular as to what he said to those he thought responsible. This did not make for popularity in some quarters, but he was universally respected and in time his great qualities were appreciated by all those whose opinions really mattered. I only got to know him properly during a long 'take-over' at the Ministry in 1946-47, when the integration of the VD clinics into the National Health Service was being planned. Even then his approach was a military one. He was a strong advocate of the hierarchical principle and had little faith in the post-war concept of professional egalitarianism. A good officer, he was ever solicitous for the welfare of what he called the 'non-commissioned ranks' of the service and, as we well know, fought hard for them both before and after his retirement. Much more could be said in his praise, but he would have hated a panegyric."

DR W. D. Nicol writes: "The death of Colonel Harrison signifies to those of us who worked in neurosyphilis rather the end of an era.

"The many years that the writer was in charge of the clinical direction of the Mott Clinic at Horton, he and his colleagues discovered a very good friend in Colonel Harrison. His every-ready help, his critical mind, and his encyclopaedic knowledge were invaluable to us. His widom and caution saved us from many pitfalls and hasty conclusions.

"Not only does one mourn the passing of a great authority in his subject, but one has lost a very generous friend and colleague."

The final tribute comes from $\mathrm{Mr}$ K. G. S. KENDALL, General Secretary and Registrar of the Institute of Technicians in Venereology: "Colonel L. W. Harrison will long be remembered in the hearts of non-medical VD workers everywhere, Nurses and Technicians, to Special Treatment Assistants from the Royal Army Medical Corps. His name even in life was a legend in the world of venereology. He had an enormous zest for living and an infinite capacity for work. Of commanding presence, cheerful and courteous in approach, he possessed a genial personality, a ready wit, and an extraordinary capacity for inspiring enthusiastic support and achievement. The Institute of Technicians in Venereology was his brain-child, which greatly benefited by his sage council and advice, invariably leading to shrewd and farsighted decisions. The Institute, under his wise and mature leadership, has increased mightily in stature. All who knew him will hold him in grateful and affectionate memory. We offer our sincerest sympathy to his wife and family." 